\title{
Procalcitonin Levels in Chronic Rhinosinusitis
}

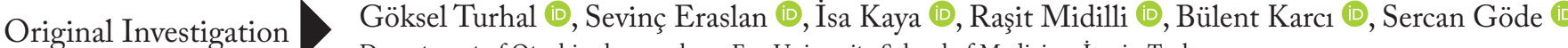 \\ Department of Otorhinolaryngology, Ege University School of Medicine, İzmir, Turkey
}

Abstract

\begin{abstract}
ORCID IDs of the authors: G.T. 0000-0003-0020-1921; S.E. 0000-0001-6608-4508;

I.K. 0000-0001-7096-4858;

R.M. 0000-0002-2862-9164;

B.K. 0000-0002-1079-4428;

S.G. 0000-0002-2148-0723.
\end{abstract}

Cite this article as: Turhal $G$, Eraslan S, Kaya I, Midilli R, Karc B, Göde S. Procalcitonin Levels in Chronic Rhinosinusitis. Turk Arch Otorhinolaryngol 2019; 57(3): 113-6.

This study was presented at the $13^{\text {th }}$ Turkish Rhinology Congress, May 4-7, 2017, Antalya, Turkey.

Corresponding Author:

Göksel Turhal; gokselturhal@gmail.com

Received Date: 07.04.2019

Accepted Date: 02.08.2019

Content of this journal is licensed under a Creative Commons Attribution 4.0 International License. Available online at www.turkarchotolaryngol.net
Objective: The aim of this study was to evaluate and compare procalcitonin levels of patients diagnosed with chronic rhinosinusitis (CRS) with nasal polyposis (CRSwNP) and CRS without nasal polyposis (CRSsNP) along with healthy controls.

Methods: A total of 67 subjects were included. Twenty-two CRSwNP patients were included in group A, $25 \mathrm{CRSsNP}$ patients in group $\mathrm{B}$, and the control group (group C) consisted of 20 healthy subjects. Procalcitonin level was assessed after CRSwNP or CRSsNP diagnosis. Healthy individuals scheduled for septorhinoplasty constituted the control group. Nasal polyposis was graded according to the Meltzer Clinical Scoring System.

Results: The mean procalcitonin levels of patients of groups A, B and C were $0.042 \pm 0.020 \mu \mathrm{g} / \mathrm{L}$, $0.031 \pm 0.016 \mu \mathrm{g} / \mathrm{L}$ and $0.031 \pm 0.010 \mu \mathrm{g} / \mathrm{L}$, respectively. Mean procalcitonin levels were significantly higher in group A compared to groups B and C $(p=0.05$ and $p=0.032)$. However, mean procalcitonin levels were not significantly different between group

\section{Introduction}

Nasal polyps are characterized by chronic mucosal inflammation caused by inappropriate or exaggerated response to different immunological stimuli or external environmental triggers resulting in dysregulated interaction between the sinus epithelium and the lymphoid system $(1,2)$. Coexistence of nasal polyps and chronic sinus disease is called chronic rhinosinusitis (CRS) with nasal polyposis (CRSwNP) (1). Chronic mucosal inflammation may also present as CRS without nasal polyposis (CRSsNP) (1-6). There is a significant overlap between chronic rhinosinusitis and a broad spectrum of inflammatory respiratory diseases. $\mathrm{CRS} w \mathrm{NP}$ is
B and group C ( $\mathrm{p}=0.962)$. Four patients $(18 \%)$ had grade 1 , three had (13.6\%) grade 2, eight had (36.4\%) grade 3 , and seven had (31.8\%) grade 4 polyposis. Mean procalcitonin levels for grades $1,2,3$ and 4 polyposis were $0.045 \pm 0.030 \mu \mathrm{g} / \mathrm{L}, \quad 0.037 \pm 0.006$ $\mu \mathrm{g} / \mathrm{L}, 0.041 \pm 0.021 \mu \mathrm{g} / \mathrm{L}$ and $0.043 \pm 0.019 \mu \mathrm{g} / \mathrm{L}$, respectively. No statistical significance was present regarding the mean procalcitonin levels of polyposis grades $(p>0.05)$.

Conclusion: Procalcitonin, which is an important inflammatory marker especially in sepsis and systemic inflammation, was significantly elevated in CRSwNP patients compared to CRSsNP patients and healthy controls. This may support the presence of chronic mucosal inflammation in CRSwNP patients. However, procalcitonin is an indirect marker of inflammation and further studies with larger patient groups are warranted.

Keywords: Rhinosinusitis, nasal polyposis, procalcitonin, inflammation typically associated with other respiratory diseases such as Aspirin-Exacerbated Respiratory Disease (AERD), or Non-Steroidal Anti-Inflammatory Drug-Exacerbated Respiratory Disease (NERD), and idiopathic bronchiectasis or comorbid asthma (7-10). Procalcitonin, which is a peptide precursor of calcitonin, is an indicator of inflammation, and an important acute phase protein used to diagnose bacterial infection and sepsis (11-14).

The aim of this study was to evaluate and compare procalcitonin levels of patients diagnosed with CRSwNP and CRSsNP along with healthy controls. 


\section{Methods}

This study was conducted between March 2016 and July 2017 at an otolaryngology clinic of a tertiary academic center. The study was approved by the Ege University Institutional Review Board (IRB approval no: 18-12T/21). Informed consent was obtained from all subjects.

A total of 67 subjects were included. Twenty-two CRSwNP patients were included in group A, $25 \mathrm{CRSsNP}$ patients in group $\mathrm{B}$ and the control group (group C) consisted of 20 healthy subjects. All patients met the chronic rhinosinusitis criteria endorsed by the European Rhinologic Society (1).

Presence of acute infection, pregnancy, history of chronic inflammatory disease, pediatric age and history of malignancy were the exclusion criteria. Patients with conditions associated with high procalcitonin levels, such as active infection, hypothyroidism, hyperthyroidism, end stage chronic kidney disease, chronic liver disease, chronic intestinal disease and chronic obstructive pulmonary disease, were also excluded. Procalcitonin levels were assessed after CRSwNP and CRSsNP diagnosis. The control subjects were recruited from among the healthy individuals scheduled for septorhinoplasty, and their procalcitonin levels were measured along with other routine blood tests during preoperative anesthesia evaluation. Nasal polyposis was graded according to the Meltzer Clinical Scoring System ( $0=$ no polyps, $1=$ polyps confined to the middle meatus, $2=$ multiple polyps occupying the middle meatus, 3 =polyps extending beyond the middle meatus, $4=$ polyps completely obstructing the nasal cavity). The relationship between procalcitonin levels and nasal polyp grade was also evaluated.

\section{Statistical Analysis}

Statistical Package for Social Sciences version 22.0 (IBM Corp.; Armonk, NY, USA) was used for statistical analysis. Independent and paired-sample t-tests were used for the analysis of parametric variables, while Wilcoxon and Mann-Whitney U tests were used for the analysis of nonparametric variables based on the distribution pattern of the data. The Shapiro-Wilk test was used to test the normality of the data. The distribution of the groups was nonparametric. Correlation analysis was performed via Pearson or Spearman correlation analysis based on the distribution pattern of the data. A p-value less than 0.05 was considered statistically significant.

\section{Results}

The mean age was $37.73 \pm 15.21$ years (range $18-75$ years), $43.80 \pm 15.67$ years (range $21-68$ years) and $35.16 \pm 15.67$ years

Table 1. Mean procalcitonin levels

\begin{tabular}{l|c|c|c}
\hline Group & $\mathbf{n}$ & $\begin{array}{c}\text { Mean } \pm \text { Standard } \\
\text { Deviation (SD) }\end{array}$ & Range \\
\hline Group A & 22 & $0.042 \pm 0.020$ & $0.02-0.09$ \\
\hline Group B & 25 & $0.031 \pm 0.016$ & $0.02-0.08$ \\
\hline Group C & 20 & $0.031 \pm 0.010$ & $0.02-0.05$ \\
\hline
\end{tabular}

(range 19-79 years) in groups A, B and C respectively. Of the 67 subjects, 24 were male and 43 were female. The groups did not differ significantly regarding gender frequency $(p>0.05)$.

The mean procalcitonin levels of patients of groups $\mathrm{A}, \mathrm{B}$ and $\mathrm{C}$ were $0.042 \pm 0.020,0.031 \pm 0.016$ and $0.031 \pm 0.010$, respectively (Table 1). Mean procalcitonin levels were significantly higher in group A compared to groups B and $C(p=0.05$ and $p=0.032)$. However, mean procalcitonin levels didn't significantly differ between group B and group C ( $\mathrm{p}=0.962)$.

Two patients (9.1\%) had underlying Samter's syndrome in Group A. Four patients (18\%) had grade 1, three had (\%13.6) grade 2 , eight had (36.4\%) grade 3 , and seven had (31.8\%) grade 4 polyposis. Mean procalcitonin levels for grade 1, 2, 3 and 4 polyposis were $0.045 \pm 0.030,0.037 \pm 0.006,0.041 \pm 0.021$ and $0.043 \pm 0.019$, respectively. No statistical significance was present regarding the mean procalcitonin levels of polyposis grades $(\mathrm{p}>0.05)$.

\section{Discussion}

The pathophysiology of chronic rhinosinusitis is still poorly understood. Many factors including allergens, toxins, bacteria, fungi, genetic predisposition, imbalance of the local or the systemic immune system, and changes in the microbiota have all been proposed as the underlying pathology (1). Chronic sinusitis is divided into two major subgroups according to the clinical findings obtained in nasal endoscopic examination and computed tomography (CT) scans: CRSwNP and CRSsNP $(1,15)$. Nasal polyps exhibit proinflammatory mediators such as leukotrienes, cytokines and extensive B cell infiltrates with local $\operatorname{IgA}, \operatorname{IgE}$ and IgG production (16). Derycke et al. (17) reported that helper $\mathrm{T}$ cells and sinonasal mucosa inflammation were significantly higher in patients with CRSwNP compared to CRSsNP and controls.

It is well known that procalcitonin levels increase significantly in the presence of bacteremia and sepsis (18-20). Although procalcitonin is primarily used to help guide physicians to support the presence of bacterial infections, previous research has reported slightly elevated procalcitonin levels during localized bacterial infection and viral infection (21). Additionally, authors of this study have previously reported significantly higher procalcitonin levels in idiopathic sudden sensorineural hearing loss patients compared to healthy individuals (22).

The aim of this study was to investigate whether there was a relationship between procalcitonin levels and presence of CRSwNP or CRSsNP. Many proinflammatory mediators and cytologic investigations were reported. However, to date only one study assessed procalcitonin levels in patients with nasal polyps. Bilici et al. (23) reported significantly higher procalcitonin levels (1319.5 pg/mL vs. $818.8 \mathrm{pg} / \mathrm{mL}$ ) in CRSwNP patients compared to CRSsNP patients with a cut-off value of $950 \mathrm{pg} / \mathrm{mL}$ (area under curve: 0.860). This study is the first to compare procalcitonin levels in $\mathrm{CRSwNP}$ and $\mathrm{CRSsNP}$ patients with healthy controls. 
Significantly higher procalcitonin levels in CRSwNP compared to both the CRSsNP and the control groups support the inflammatory hypothesis in CRSwNP patients. High procalcitonin levels in patients with nasal polyps and chronic rhinosinusitis may support bacterial etiology and chronic mucosal inflammation. According to recent studies there is indirect evidence regarding exposure to staphylococcal exotoxins in CRSwNP patients $(17,24,25)$. Staphylococcal exotoxins have the potential to act as superantigens and directly stimulate a massive inflammatory response. Wang et al. (25) reported the presence of superantigen toxins in 14 of 29 patients with CRSwNP, with SEB and TSST-1 being the most common antigens. Elevated procalcitonin levels further support the etiology of bacterial infection.

Aspirin-exacerbated respiratory disease (AERD), also referred to as Samter's syndrome, consists of hypersensitivity to non-steroidal anti-inflammatory drugs, nasal polyposis and asthma which is characterized by eicosanoid imbalance. $\mathrm{Na}-$ sal polyps of these patients are intensely eosinophilic. Additionally, CT findings of Sampter's syndrome patients almost universally reveal complete or near-complete opacification of the paranasal sinuses $(26,27)$. The intense inflammatory nature of CRSwNP patients with Samter's syndrome wasn't associated with procalcitonin levels in this study. However, the results do not suffice to draw a conclusion because of the very limited sample size of CRSwNP patients with Samter's syndrome.

The major limitation of this study may be the small sample size and the lack of cytologic examination. Correlation with cytologic data and procalcitonin levels may be another area of future research. At this stage, the clinical applications for monitoring procalcitonin levels in nasal polyposis patients are limited; however, higher levels may give an idea about persistent and recurrent diseases as procalcitonin supports the proinflammatory nature of this disease.

\section{Conclusion}

Procalcitonin, which is an important inflammatory marker especially in sepsis and systemic inflammation, is significantly elevated in CRSwNP patients compared to CRSsNP patients and healthy controls. This may support the presence of chronic mucosal inflammation in CRSwNP patients. Nevertheless, procalcitonin is an indirect marker of inflammation and further studies with larger patient groups are warranted.

Ethics Committee Approval: Ethics committee approval was received for this study from the Ethics Committee of Ege University School of Medicine (18-12T/21).

Informed Consent: Written informed consent was obtained from patients who participated in this study.

Peer-review: Externally peer-reviewed.

Author Contributions: Concept - S.G., B.K., R.M.; Design - S.G., B.K., R.M.; Supervision - S.G., B.K., R.M.; Resource - G.T., S.E., İ.K.;
Materials - G.T., S.E., İ.K.; Data Collection and/or Processing - G.T., S.E., İ.K.; Analysis and/or Interpretation - G.T., S.E., S.G.; Literature Search - G.T., S.E., I.K.; Writing - G.T., S.E., S.G.; Critical Reviews - S.G., B.K., R.M.

Conflict of Interest: The authors have no conflicts of interest to declare.

Financial Disclosure: The authors declared that this study has received no financial support.

\section{References}

1. Fokkens WJ, Lund VJ, Mullol J, Bachert C, Alobid I, Baroody F, et al. European position paper on rhinosinusitis and nasal polyps 2012. Rhinol 2012; 50: 1-298. [CrossRef]

2. Kern RC, Conley DB, Walsh W, Chandra R, Kato A, Tripathi-Peters A, et al. Perspectives on the etiology of chronic rhinosinusitis: An immune barrier hypothesis. Am J Rhinol 2008; 22: 549-59. [CrossRef]

3. Hopkins C. Chronic rhinosinusitis with nasal polyps. N Engl J Med 2019; 381: 55-63. [CrossRef]

4. Rosenfeld RM. Clinical practice guideline on adult sinusitis. Otolaryngol Head Neck Surg 2007; 137: 365-77. [CrossRef]

5. Erskine S, Hopkins C, Kumar N, Wilson J, Clark A, Robertson A, et al. A cross sectional analysis of a case-control study about quality of life in CRS in the UK; a comparison between CRS subtypes. Rhinology 2016; 54: 311-5. [CrossRef]

6. Van Crombruggen K, Van Bruaene N, Holtappels G, Bachert C. Chronic sinusitis and rhinitis: Clinical terminology Chronic rhinosinusitis further supported. Rhinology 2010; 48: 54-8. [CrossRef]

7. Guilemany JM, Angrill J, Alobid I, Centellas S, Pujols L, Bartra J, et al. United airways again: high prevalence of rhinosinusitis and nasal polyps in bronchiectasis. Allergy 2009; 64: 790-7. [CrossRef]

8. Alobid I, Cardelus S, Benitez P, Guilemany JM, Roca-Ferrer J, Picado C, et al. Persistent asthma has an accumulative impact on the loss of smell in patients with nasal polyposis. Rhinology 2011; 49: 519-24.

9. Guilemany JM, Angrill J, Alobid I, Centellas S, Prades E, Roca J, et al. United airways: the impact of chronic rhinosinusitis and nasal polyps in bronchiectasic patient's quality of life. Allergy 2009; 64: 1524-9. [CrossRef]

10. Massoth L, Anderson C, McKinney KA. Asthma and chronic rhinosinusitis: Diagnosis and medical management. Med Sci (Basel) 2019; 7: E53. [CrossRef]

11. Aloisio E, Dolci A, Panteghini M. Procalcitonin: Between evidence and critical issues. Clin Chim Acta 2019; 496: 7-12. [CrossRef]

12. Schuetz P, Bretscher C, Bernasconi L, Mueller B. Overview of procalcitonin assays and procalcitonin-guided protocols for the management of patients with infections and sepsis. Expert Rev Mol Diagn 2017; 17: 593-601. [CrossRef]

13. Rey C, Los Arcos M, Concha A, Medina A, Prieto S, Martinez P, et al. Procalcitonin and C-reactive protein as markers of systemic inflammatory response syndrome severity in critically ill children. Intensive Care Med 2007; 33: 477-84. [CrossRef]

14. Markanday A. Acute phase reactants in Infections: Evidence-based review and a guide for clinicians. Open Forum Infect Dis 2015; 2: ofv098. [CrossRef]

15. Bachert C, Zhang L, Gevaert P. Current and future treatment options for adult chronic rhinosinusitis: Focus on nasal polyposis. J Allergy Clin Immunol 2015; 136: 1431-40. [CrossRef] 
16. Lam K, Schleimer R, Kern RC. The etiology and pathogenesis of chronic rhinosinusitis: A review of current hypotheses. Curr Allergy Asthma Rep 2015; 15: 41. [CrossRef]

17. Derycke L, Eyerich S, Van Crombruggen K, Pérez-Novo C, Holtappels $\mathrm{G}$, Deruyck N, et al. Mixed $\mathrm{T}$ helper cell signatures in chronic rhinosinusitis with and without polyps. PLoS One 2014; 9: e97581. [CrossRef]

18. Mitaka C. Clinical laboratory differentiation of infectious versus non-infectious systemic inflammatory response syndrome. Clin Chim Acta 2005; 351: 17-29. [CrossRef]

19. Becker KL, Snider R, Nylen ES. Procalcitonin assay in systemic inflammation, infection, and sepsis: Clinical utility and limitations. Crit Care Med 2008; 36: 941-52. [CrossRef]

20. Limper M, de Kruif MD, Duits AJ, Brandjes DP, van Gorp EC. The diagnostic role of procalcitonin and other biomarkers in discriminating infectious from non-infectious fever. J Infect 2010; 60: 409-16. [CrossRef]

21. Assicot M, Gendrel D, Carsin H, Raymond J, Guilbaud J, Bohuon C. High serum procalcitonin concentrations in patients with sepsis and infection. Lancet 1993; 341: 515-8. [CrossRef]
22. Göde S, Turhal G, Kaya İ, Mavili Hİ, Kirazlı T. Evaluation of procalcitonin and hs-CRP levels in sudden sensorineural hearing loss. J Int Adv Otol 2018; 14: 44-7. [CrossRef]

23. Bilici S, Cinar Z, Yigit O, Cakir M, Yigit E, Uzun H. Does procalcitonin have a role in the pathogenesis of nasal polyp? Eur Arch Otorhinolaryngol 2019; 276: 1367-72. [CrossRef]

24. Ou J, Wang J, Xu Y, Tao ZZ, Kong YG, Chen SM, et al. Staphylococcus aureus superantigens are associated with chronic rhinosinusitis with nasal polyps: A meta-analysis. Eur Arch Otorhinolaryngol 2014; 271: 2729-36. [CrossRef]

25. Wang M, Shi P, Chen B, Zhang H, Jian J, Chen X, et al. The role of superantigens in chronic rhinosinusitis with nasal polyps. ORL J Otorhinolaryngol Relat Spec 2008; 70: 97-103. [CrossRef]

26. Stevenson DD, Simon RR, Zuraw BL. Sensitivity to Aspirin and NSAIDs. Philadelphia: Mosby, 2003.

27. Mascia K, Borish L, Patrie J, Hunt J, Phillips CD, Steinke JW. Chronic hyperplastic eosinophilic sinusitis as a predictor of aspirin-exacerbated respiratory disease. Ann Allergy Asthma Immunol 2005; 94: 652-7. [CrossRef] 